\title{
An investigation on behavioral biases in ship investments of small-sized shipping companies
}

\author{
Ersin Firat Akgul
}

Department of Maritime Business Administration,

Bandirma Onyedi Eylul University Maritime Faculty, Balikesir, Turkey, and

Dokuz Eylul University Maritime Faculty, Izmir, Turkey

\author{
Ismail Bilge Cetin \\ Department of Maritime Business Administration,
}

\begin{abstract}
Purpose - This study aims to explain the facts about behavioral biases that cannot be explained by rational patterns in ship investments of small-size shipping companies.

Design/methodology/approach - A qualitative approach was adopted in this study. The systematic approach of Wolcott (1994) and the action flows proposed by Miles and Huberman (1994) were taken into consideration.

Findings - Factors affecting ship investments are classified as ship finance, market timing, ship specifications and profile and business models of ship investors. In addition, behavioral biases that stand out under each theme are explained in the light of behavioral finance literature.
\end{abstract}

Originality/value - The originality of this study rests on the lack of studies on behavioral aspects of ship investments.

Keywords Ship investment, Behavioral bias, Small-sized shipping companies

Paper type Research paper

\section{Introduction}

Maritime transport facilitates the access of countries with a coastline to the Black Sea, Mediterranean and Continental Europe to international markets. Consequently, transportation systems and ship structures are designed to meet the need for efficient transportation of goods with different characteristics in the region (Panayides et al., 2011, p. 681). Small sized cargo ships play an important role in regional dry cargo transportation. The Turkish-owned coaster fleet has the largest share in regional dry cargo trade. According to IHS Markit Sea-web database, the Turkish-owned coaster fleet consists of 765 ships with around 3.44 million dwt, as of the beginning of 2018 , that accounts for $35 \%$ of total coaster supply by total carrying capacity in the region.

After the collapse of the former Soviet bloc and the disintegration of state-owned fleets, the number of independent shipowners in the dry bulk market has increased

\section{(C) Pacific Star Group Education Foundation. Licensed re-use rights only}

The authors express their gratitude to two anonymous referees for pointing out certain shortcomings in the original draft. These comments have enabled a number of improvements to the final version. The authors also gratefully acknowledge the participants for providing data and scholars for peer review processes.
Received 4 August 2020 Revised 30 October 2020 11 November 2020 15 January 2021 15 March 2021 Accepted 19 March 2021

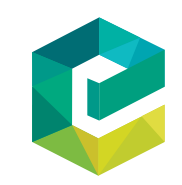

Maritime Business Review Vol. 6 No. 4,2021 pp. $377-391$

Emerald Publishing Limited 2397-3757 8-2020-0049 
MABR

6,4

(Celik Girgin et al., 2018, p. 3). Judgmental impacts of decision-makers substantially drive the market (Duru and Yoshida, 2009, pp. 191-192). This also affects ship investments, which are of great importance in the long-term sustainability of the shipping industry (Stokes, 1996, pp. 397-398; Gong et al., 2013, p. 1). Although ship investments based on the investors' ability to read the market provide significant returns to the investors (Angelopoulos et al., 2016, p. 229; Chiste and van Vuuren, 2014, p. 2), wrong ship investments may lead to waste of financial resources and cause bankruptcy of the firms operating in this business (Drobetz et al.,2016, p. 26). In this sense, cognitive capacity of decision-makers gains importance. However, as indicated by Tversky and Kahneman (1974), it is difficult to consider all possible alternatives in uncertain and complex decision processes. Therefore, using heuristics under uncertainty relieves the decision-maker from the workload of evaluating possibilities and accelerates the process. However, such heuristics may lead to systematic errors that are defined as behavioral biases (Kahneman and Riepe, 1998, p. 53).

In this study, ship investments in small-sized shipping companies are assumed to be contrary to the rational patterns, and we aimed to test this assumption with the case study. As emphasized by Yin (1994), case studies are important in explaining the facts. As the majority of the merchant fleet in Turkey is composed of coasters, we analyzed the coaster investments of Turkish shipowners based on stakeholder perspective. The originality of this study rests on the lack of studies on behavioral aspects of ship investments. The remainder of this paper is organized as follows. Theoretical background including the role of psychology in economic behavior and ship investments is discussed in the second section. Methodology, including data collection, sampling, data analysis and rigor of the study, is explained in the third section. Then, findings are discussed with the current literature in the fourth section, and the study ends with the conclusion.

\section{Theoretical background}

\subsection{Role of psychology in economic behavior}

Behaviors of investors and their consequences faced in the reality are neglected in traditional approaches. It is assumed that investors always make rational decisions although cognitive and emotional weaknesses have an effect on decision-making process of investors (Baker and Nofsinger, 2002, p. 97). However, decision-making mechanisms of investors may deviate from rationality, and many financial models do not fit the market in many cases (Barber and Odean, 2000). Behavioral finance, which includes investor psychology and determinants of human behavior, fills this gap accordingly. Kahneman and Tversky (1979) is the most popular study, and "prospect theory" was proposed as an alternative model that emphasizes the shortcomings of the expected utility theory (Kahneman and Tversky, 1979, p. 263). Prospect theory suggests that individuals adhere to a limited number of principles that simplify the difficulties experienced in predicting events and assessing possibilities.

Numerous cognitive biases have been identified since the seminal study of Kahneman and Tversky (1979) on systematic errors in human decisions. These systematic errors, from daily routine decisions to strategic decisions, play an important role in shaping decisions. Some biases may overlap in certain situations or differ in scope. Therefore, there are studies for classification of biases according to a certain systematic (Hirshleifer, 2001; Kahneman and Riepe, 1998; Shefrin, 2000; Goldberg and von Nitzsch, 2001; Barberis and Thaler, 2003; Rabin, 1998; Carter et al., 2007).

\subsection{Ship investments}

Freight rates and secondhand ship prices react instantly against changes in the balance of supply and demand. Temporary imbalances between demand for international maritime 
transport and current supply capacity may lead to unexpected changes in freight rates (Drobetz et al., 2016, p. 27; Scarsi, 2007, p. 580). In such an environment, traditional ship valuation models may not be valid because of uncertainty. Therefore, new methods have emerged to estimate the value of the ships especially in uncertain environment (Dikos and Marcus, 2003). In this respect, real options analysis gives more robust results than the traditional discounted cash flow (DCF) approach in a market where uncertainty exists (Bendall and Stent, 2003; 2007, Yin et al., 2018).

Considering the factors that have an impact on ship prices, the relationship between secondhand ship price and earnings can be considered as one of the important signals for the estimation of future price of the secondhand ships (Alizadeh and Nomikos, 2006, 2007), and secondhand ship prices are much more affected by new building prices (Tsolakis et al., 2003). New building price is more volatile than time charter rates and secondhand prices, when the freight rates are lower, and also secondhand ship prices increase when the freight market is stable (Fan and Yin, 2016). Besides, there is a positive relationship between ship price and ship sale and purchase volume in dry bulk market (Alizadeh and Nomikos, 2003). On the other hand, there is a negative relation between incentives and investment levels (Marlow, 1991).

It is important to be able to predict future cash flow with the least possible error, as ship investments are shaped according to freight rate estimations. There is a wide variety of studies on freight estimation in the current literature. Estimation results are compared in the studies in which econometric models, hybrid models and soft computing models are considered (Alizadeh et al., 2007; Bulut et al., 2012; Fan et al., 2013; Munm and Schramm, 2020).

Despite the knowledge and experience in the dry cargo market, the reason why the investors still make mistakes in ship investments is the lack of market analysis (Scarsi, 2007). Decision-makers in shipping companies overvalue demand for shipping services and invest more during peak times, and the behavior of competitors are undervalued (Greenwood and Hanson, 2015). Besides, time to build decreases at a time when investment volatility increases (Kalouptsidi, 2014). Considering capacity expansion decisions, especially of container liners, market-driven factors have an effect even if the order book is full (Fan and Luo, 2013). Regarding the optimum timing of ship investment, investing in secondhand ships is more rational in rising rates, whereas new building ships should be more preferable in low rates because of the optimistic expectations for the future in tanker market (Merikas et al., 2008). In reality, the situation is different. Specifically, ship investments increase at peak market where the ship prices reach highest levels. However, return on equity rates considerably decrease at the same time (Bulut et al., 2013).

In summary, previous studies on ship investments are directly linked to the empirical studies using secondary data sources. More specifically, majority of the studies carried out in this context are predominantly on market research to determine the appropriate conditions for ship valuation and also the investor behavior under different conditions. In this context, the motivation of this study rests on the lack of existing literature on the factors that drive the ship investment decisions and also behavioral biases of decision-makers.

\section{Methodology and design}

Considering the need of carrying out a preliminary study on the subject, we adopted a qualitative approach in this study to present an exploratory and realistic picture on the existence and meaning of the phenomenon.

\subsection{Data collection}

Data were collected based on interview, as one of the qualitative data collection techniques (Patton, 2002). In addition, it is one of the most powerful methods to gather information on

\section{Behavioral biases in ship investments}


MABR

6,4

experiences, thoughts, feelings and knowledge of individuals on a certain subject (Bogdan and Biklen, 1992). In this sense, a semi-structured interview was conducted in each interview, as it is both standard and flexible to a certain extent. In order for the participants to feel comfortable and to answer questions frankly, the interviews were conducted at the addresses of each participant. The questions in the interviews are listed in Appendix 1. Assuming that the data are embedded and meaningful structures should be revealed, data were collected by the first author according to the role of "miner" as defined by Kvale (1996). The theoretical explanations were shared with the participants not to face any misunderstanding, and whenever the doubts on how to respond to the questions occurred, the questions were clarified and simplified by giving comprehensible examples. Some questions were asked differently to check if the participant gives the consistent responses. To obtain independent perspectives of each participant, responses collected from previous interviews were not shared with the existing participant. The data obtained were compiled and compared with the previous step within the scope of the cyclical process. The field researches were terminated when the required saturation of data was reached.

\subsection{Sampling}

As it is very difficult to identify valuable data sources and, generally, reference is required to reach these sources, snowball sampling was preferred in this study. Although stakeholders include a wide variety of market participants, they are limited to experts serving in the sector and shipowners in line with the scope and purpose of the study because the source of the data determines the quality of the study. Therefore, we tried to reach those who have the most valuable information. In this sense, after the initial research group was determined, participants in each interview were asked to provide references about the participants who might be involved in the next interview. In total, three sale and purchase brokers, four consultants, a secretary general, director and research specialist from two different associations in Turkey and 20 ship investors were interviewed. Supporting information regarding the profile of the participants and details of interviews can be found on link https:/drive.google.com/file/d/ 14Mfzkglicm68hb67bU426UPFccpET305/view?usp=sharing. Due to the anonymity reasons, names of the participants and the institutions they work for were kept confidential.

\subsection{Data analysis}

In line with the purpose of the study, the systematic approach of Wolcott (1994), which includes the descriptive approach in which the statements shared by the participants are conveyed as original as possible, aims to reach various themes by making some causal and explanatory implications. To implement the systematic approach, we considered the action flows proposed by Miles and Huberman (1994). Specifically, the quotations in line with the purpose of the research were filtered and coded under certain themes to reach a simpler data set. Emerging concepts and themes were clarified to reach certain results. In the last stage, the findings were interpreted, compared and confirmed.

A two-step coding procedure was applied. In the first step, data obtained from the participants were coded with the relevant code. In the second step, themes were determined by classifying context-specific interpretations based on the relevant codes, then constant comparisons between the themes were used to avoid overlaps, and finally, definite themes were determined. In line with Gioia et al. (2013, p. 21), the data structure shown in Appendix 2 visualizes how the data progressed in the analyses. Codes in bold were described as behavioral biases within the scope of the aggregate dimension and discussed in comparison with the current literature. Both in coding and in interpretation phases, we conducted peer review examinations to confirm the findings. 


\section{Findings and discussion}

Themes, namely, market timing, ship specifications, profile and business models of ship investors and ship finance were reached by analyzing the data collected from the participants. To achieve the aim of this study, the facts that cannot be explained with rational behavior patterns in each theme are explained in the light of behavioral finance literature. In addition, it was determined that some behavioral biases stand out within the scope of more than one theme. The relationship between the detected behavioral biases and themes is visualized in Figure 1.

\subsection{Market timing}

Market timing is considered as an ability to read the market properly and obtain high-level commercial and technical up-to-date data, and it is vital to achieve effectiveness of ship investments. The findings of this study is consistent with the previous studies (Alizadeh and Nomikos, 2006; Chiste and van Vuuren, 2014; Alizadeh and Nomikos, 2007; Scarsi, 2007). Specifically, it is important to invest by considering certain price formations, as there is a weak form of efficiency in the dry bulk shipping industry (Kavussanos and Alizadeh, 2002; Glen, 1997; Hale and Vanags, 1992). Therefore, huge profits could be obtained by implementing trading strategies based on market timing, where ship prices consistently deviate from their fundamental values.

\subsubsection{Behavioral biases related to market timing}

4.1.1.1 Desirability bias. In line with the findings of Bulut et al. (2013), asset pricing may increase depending on the extreme optimism triggered by positive developments. In such environment, in which asset prices are high, ship investments also increase. Greenwood and Hanson (2015) and Scarsi (2007) explained this behavior as the firms overestimate demand for shipping services, the actions of the competitors are ignored or undervalued, and majority of them follow their intuition. It is highly probable to see ups and downs in the market where cyclicality prevails (Chiste and van Vuuren, 2014, pp. 1-2). Accordingly, the assumption that high market conditions will remain high in excess of optimistic expectations cannot be explained by rational behavior patterns. However, opinions of participants show that overoptimistic expectations in high market conditions affect ship investments. This can be considered as an evidence of the existence of desirability bias. Desirability bias, which is defined as the tendency to be overoptimistic in evaluating the probability of desired outcomes,

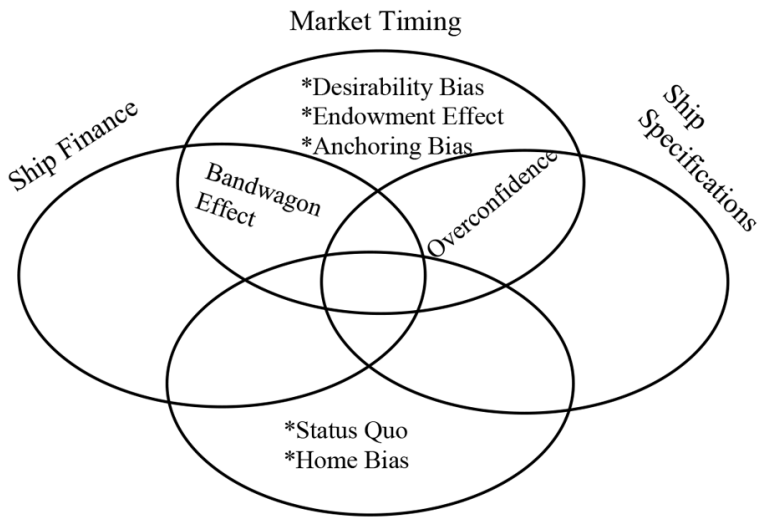

Profile and Business Models of Ship Investors

Figure 1. Behavioral biases in ship investments in Turkey 
MABR

6,4 also known in the literature as wishful thinking (Hogarth, 1987) or outcome bias (Cohen and Wallsten, 1992), first came forward as a bias emphasized by McGregor (1938) (Olsen, 1997, pp. 65-66). Participants' views on this issue are exemplified as follows.

SI-2: The market was very active and it was almost impossible to find ships for sale. [...] I searched for ships until March 2008 and bought a ship built in 1984 for $\$ 3.1$ million. Then I wanted to hire the ship as soon as possible to subsidize the extra amount I spent. However, things did not go well as expected. When the market fell, even the gains of three ships were not enough to pay off the debt of this ship.

SI-15: Our 1983-Turkish-built ship that was purchased in May 2005 for $\$ 1.6$ million, received a $\$ 2$ million offer in January 2008. [.. .] the ship was sold. After selling the ship, we talked to the partners. I thought there was a balloon ready to explode at any moment in the market. We were four partners [.. .] Everyone except me decided to invest [.. .] My prediction was unfortunately realized. The partners bought two ships and we had very serious trouble. However, if we had waited 5 months with the cash we obtained from the sale, we could have bought more ships with the amount we paid to the ships we bought.

4.1.1.2 Endowment effect. One of the points emphasized by the participants is that as Turkish coaster owners are directly involved in the operation activities and their ships carry the names of the people they care, an emotional connection between the owner and the ship exists. From this point of view, there is great resistance to the sale of ships, even under favorable conditions. The opinion of one of the participants on this subject is as follows.

SI-14: My father was the owner and the captain of the ship [...] I have a bachelor degree on this field, but I have less connection with the ship than my father. I visit our ships with my technical superintendent. However, the others before us were dismantling the main engine themselves. [...] it seems that we will move towards rationality with the change of generations and the lack of connection of the shipowners with their ships.

Especially the ships operated by the old generation shipowners, the emotional connection may occur between the owner and the ship that has the names of mother, sister, spouse etc. Accordingly, it will be difficult to sell the ship. One of the participants emphasized the issue with the following words:

C-3: When the ship is being invested, it is not questioned whether the market is suitable or not [...] Names of beloved people, especially their mothers, daughters, spouses etc. are given to the ships, which makes a connection with the ship.

This can be explained by the behavioral bias known as "endowment effect" in the literature. The endowment effect is a bias in which people value their assets more than those that are equivalent or better options (Kahneman et al., 1991, p. 194). In this case, the opportunity cost is considerably low (Thaler, 1980, p. 39). However, holding an asset that is overvalued can cause great harm to its owner, as opportunity costs are undervalued in line with the study of Duru (2016).

4.1.1.3 Anchoring bias. Tversky and Kahneman (1974) defined "anchoring bias" as a situation in which the known previous value of a variable is considered as a reference for estimation future value of the same variable. Experiences and present observations are often used to determine the reference (Baker and Nofsinger, 2002, pp. 106-107). Wright and Anderson (1989) emphasized that the anchoring has a major role on investors' decisionmaking processes. According to the statements of the participants, anchoring bias was detected in ship investments of small-sized shipping companies in Turkey. It was emphasized by a participant as follows:

SI-4: In 2007, one of the participation banks was going to finance a $\$ 19$ million ship, I looked at the ship over the age of 20 and will be scrapped in 3 years. If the investor add another $\$ 5$ million on the total amount, he was able to order a new building ship in China. However, at 
that time, there were so many queue at the shipyards, and buying second hand ships would make more sense, and the ships were able to pay off their debt in only 1 year.

Accordingly, the investors might anchor to the extreme freight levels and ship prices, invest in ships when they consider the previous price formations as a reference and compare them with the current price levels. The anchoring bias arises in the comparison of the current prices of secondhand and new building ships as well as in the comparison of past and present price formations of the ships is emphasized as follows:

SI-9: New building cost of 5.000 dwt ship is estimated $\$ 8$ million today [...] In today's conditions, a ship that costs $\$ 8$ million earns $\$ 2,000$ per day and $\$ 660,000$ per year. If you consider \$1-2 million opportunity cost of interest earnings, the period would be 15 years [....] I am 60 years old and I do not have an intention to work for 15 years. Besides, you cannot even see after 3 years.

Investing in a ship with relatively old technology can harm financial and operational performance in the medium and long term. As is now, the finding that investing in secondhand ships rather than new building ships in bad market conditions would be a more logical decision contradicts with the literature. More specifically, according to Merikas et al. (2008), secondhand ship investment is more logical during boom times to meet demand, whereas new building ship investments would be more logical in bad market conditions as a result of optimistic expectations on future.

4.1.1.4 Overconfidence. Studies show that investors are overconfident on their ability to invest (Daniel et al., 1998; Barber and Odean, 2000; Gervais and Odean, 2001; Statman et al., 2006). Considering that there is a centralized decision-making mechanism in Turkish coaster market, one of the main issues is that the decision-makers exaggerate their ability to read the market and invest in ships according to their cognitive capacity especially in peak market conditions. This was emphasized by a participant as follows.

SI-19: We heard that ships with 4-5 partners were purchased with a capital of 100,000 200,000 dollars per person after 2009, but then they went bankrupt. Each of them was very good broker, master, mechanic but business administration and financial management is a very distinct virtue.

This is consistent with the study of Duru (2013), suggesting that investors behave impatiently with overconfidence about the timing of investment, especially in the high liquidity environment, and that historical evidence requires otherwise. Ship investments made without any feasibility studies were quite high especially in terms of investment literacy. This was indicated by a participant as follows. From this point of view, overconfidence stands out in explaining such behaviors.

SI-4: It is extremely luxurious for the coaster owners to do an academic study and turn to investment. Such analyzes are seen as time consuming and financially troublesome.

4.1.1.5 Bandwagon effect (herding). An investor who is devoted to the herding ignores his/ her knowledge and shapes his/her decisions by considering the behavior of others in the market (Christie and Huang, 1995, p. 31; Nofsinger and Sias, 1999, p. 2263). The higher the demand, the higher the price of the asset, and inevitably the market will bubble (Lyungqvist and Wilhelm, 2003, p. 723; Stone and Ziemba, 1993, pp. 161-163). Majority of the ship investors have a tendency to be in line with the preferences of other participants (Duru, 2013), and these behaviors cause ups and downs in the market (Hampton, 1991). This behavior has been identified as an emerging phenomenon in this study as stated by a participant as follows. Bandwagon effect stands out among other behavioral biases in explaining such behaviors.

SI-20: Most of the families in shipping business are close to each other. When a family invest in a ship, the other family invest as well, regardless of ship prices. The main motivation here is "if they bought a ship, we could buy as well." 


\section{MABR}

6,4

\section{4}

4.2 Profile and business models of ship investors

The findings of central decision-making mechanism in family businesses and the tendency of family-owned shipping companies to invest in ships based on poor analytical decisionmaking are consistent with implications of Scarsi (2007). As a matter of fact, Arslan (2008) states that institutionalized shipping firms take advantage of rational decision models and shape ship investment decisions using financial analysis methods. It was emphasized that investments were shaped according to business models adopted. It was emphasized that, albeit to a limited extent, some investors classified as speculators (Alizadeh et al., 2017, p. 98) have adopted asset play approach and shape their investments accordingly.

4.2.1 Behavioral biases related to profile and business models of ship investors

4.2.1.1 Status quo. Strategic decisions, such as investments, are mainly made by the shipowner and/or another member of the family rather than professionals as asserted by Cetin and Cerit (2014). Cariou and Wolff (2011) explained this behavior because of the age of the ship, the small tonnage and the small number of ships in the fleet. As emphasized in this study, the fact that coaster owners do not want to hand over the decision mechanism to professionals can be explained by the fear of losing control.

SP-3: In the companies operating coasters, the decision maker is the shipowner, and this is important for him/her. Helshe wants to dominate the ship. Helshe wants to have a control on the ship. This is also the case with the coaster fleet renewal project. Being a shareholder is not very attractive for them, there is a fear of losing control.

SI-2: There is a large group of shipowners who do not adopt partnership with the state. Unfortunately, we could not capture the spirit of acting together.

They tend to maintain the current situation because the disadvantages of different models are perceived to be higher than to maintain the current situation (Samuelson and Zeckhauser, 1988, p. 8). In explaining the status quo bias, prospect theory of Kahneman and Tversky (1979) is the most widely accepted theory. Accordingly, investors tend to maintain the current situation to avoid loss.

4.2.1.2 Home bias. Another irrational behavior emphasized by the participants in the study is that Turkish coaster owners focus on investment alternatives that they can run as close to home as possible and ignore the other alternatives. One of the participants emphasized the issue as follows.

SI-5: I do not prefer a big ship since it is tiring. You need to overcome time notion. I have to be in charge, but on the other hand, I have my own personal life. That is why I prefer to have an investment considering my own time zone.

Investors take place in the markets close to their home country and ignore alternatives other than those markets because of the lack of information about foreign markets, difficulties in monitoring the market and poor qualified and/or low credible information (Kang and Stulz, 1997; Ahearne et al., 2004). Graham et al. (2009) explained this with the competencies of investors.

\subsection{Ship specifications and overconfidence as behavioral bias}

Ship specifications are one of the factors driving ship investments. According to the findings of this study, ship investors tend to prefer ships with well-known machines and auxiliaries, as office staff and crew on board are familiar with their working principles, maintenance and repair conditions. Moreover, the fuel type used by the main engine and the fuel consumption of the main engine have also been detected as one of the points considered in the ship investments.

Ship design was emphasized as another technical feature considered in ship investments in Turkey. Particularly, it was stated that ships capable of carrying all types of cargo can be 
invested regardless of the circumstances. The other technical issues were determined as the age and condition of the ship. It was stated that the investors were inclined to buy the ship at an affordable price and then carry out the necessary repair and maintenance. Another prominent technical issue in ship investments in Turkey was found as ship tonnage. It was stated that ship tonnage gains importance in investments, as the ships are preferred in the region that are able to carry the cargo in the range of 3,000-4,000 dwt and 10,000-12,000 dwt. "Overconfidence bias" emerges within the scope of the findings on technical issues. In particular, it was stated that ship investors in Turkey prefer ships with designs that are suitable for their budgets, and the cargo that can be carried with that ship is searched after the ship is purchased.

SI-1: Unfortunately, primary concern for us is the budget. We think that: "I' $m$ going to build a ship and I have a million usd in my pocket". On the other side, the European thinks: "I have an intention to build ship with certain specifications and how much does it cost, and how much money do Ineed?" That is the logic.

It was also detected that there are ship investors who were disappointed due to purchase of high age and low-condition ships of European shipowners from affordable prices. The reason behind this behavior could be the thought that the ship would be easily repaired at affordable costs as stated as follows.

SI-14: Since the main idea is to gain profit, the amount to be invested gains importance. Therefore, buying the ship at an affordable becomes the primary goal. However, the price of such ships will be lower because of their current condition, draft, machine size, etc.

Although they have the high-level technologies of the time they were built, in an environment where technology and quality standards are constantly improving, it is very difficult to operate such ships efficiently and profitably.

\subsection{Ship finance and bandwagon effect (herding) as behavioral bias}

Some investors suffer considerable losses from their ship investments because of the misleading of banks. Banks have provided low-cost financing to many industries, including the maritime industry, as the central banks of developed economies have increased the money supply to stimulate the economy. In such an environment with favorable credit conditions, ships were in demand at very high prices. One of the participants shared his views over the issue as follows:

SI-15: A few doctors decided to establish a hospital before 2008. However, expert in a bank said, "shipping is very good nowadays, you should try your chance". There has been such a misdirection, but these are individual events.

It was impossible to consider the ships as collateral due to dramatic decline in ship prices. Duru (2016) and Bulut et al. (2013) emphasized that in an environment where the financing conditions are quite good and almost everyone invests, it is difficult to resist to buy ships, and many market participants invest in compliance with majority. This is consistent with the findings of this study. In summary, bandwagon effect, or herding, occurs in high liquidity conditions.

\section{Conclusion}

Investment decision is a critical action for a shipping company in its business life to survive and grow. The effects of behavioral biases need to be considered by ship investors to make sound decisions and not to face unexpected results. In this study, it is intended to explain and interpret the relations that dominate a phenomenon with a certain systematic approach. In this study, instead of making a prediction for ship investments, it is aimed to explain the facts about behavioral biases that cannot be 
MABR

6,4

explained by rational patterns in ship investments of small-size shipping companies with a qualitative research perspective.

This study is subject to various limitations associated with the qualitative research strategy. The main limitation is the weakness of external validity of the findings because that it is focused on coaster investments in Turkey. In this context, investments of shipowners operating in different markets can be analyzed and compared with the findings. Another limitation of this study is the number of participants and the data analyzed. Therefore, studies with a wider and more diverse sample could be designed. Last, but not least, the findings can be tested with quantitative methods.

\section{References}

Ahearne, A.G., Griever, W.L. and Warnock, F.E. (2004), "Information costs and home bias: an analysis of US holdings of foreign equities", Journal of International Economics, Vol. 62 No. 2, pp. 313-336.

Alizadeh, A.H. and Nomikos, N. (2003), "The price-volume relationship in the sale and purchase market for dry bulk vessels", Maritime Policy and Management, Vol. 30 No. 4, pp. 321-337.

Alizadeh, A.H. and Nomikos, N. (2007), "Investment timing and trading strategies in the sale and purchase market for ships", Transportation Research Part B: Methodological, Vol. 41 No. 1, pp. 126-143.

Alizadeh, A.H., Adland, R.O. and Koekebakker, S. (2007), "Predictive power and unbiasedness of implied forward charter rates", Journal of Forecasting, Vol. 26 No. 6, pp. 385-403.

Alizadeh, A.H. and Nomikos, N.K. (2006), "Trading strategies in the market for tankers", Maritime Policy and Management, Vol. 33 No. 2, pp. 119-140.

Alizadeh, A.H., Thanopoulou, H. and Yip, T.L. (2017), "Investors' behavior and dynamics of ship prices: a heterogeneous agent model", Transportation Research Part E: Logistics and Transportation Review, Vol. 106, pp. 98-114.

Angelopoulos, J., Duru, O. and Chlomoudis, C. (2016), "Spectral dynamics of dry cargo shipping markets theory of long waves - fact or artifact?", International Journal of Transport Economics, Vol. 43 No. 3, pp. 227-245.

Arslan, T. (2008), "Stratejik bir karar: gemi alım-satımı zamanlaması", Dokuz Eylül Üniversitesi İşletme Fakültesi Dergisi, Vol. 9 No. 2, pp. 227-255.

Baker, H. and Nofsinger, J. (2002), "Psychological biases of investors", Financial Services Review, Vol. 11 No. 2, pp. 97-116.

Barber, B. and Odean, T. (2000), "Trading is hazardous to your health: the common stock investment performance of individual investors", The Journal of Finance, Vol. 55 No. 2, pp. 773-806.

Barberis, N.C. and Thaler, R.H. (2003), "A survey of behavioral finance", in Constantinides, G.M., Harris, M. and Stulz, R.M. (Eds), Handbook of the Economics of Finance Volume 1B, Elsevier, Amsterdam, pp. 1053-1123.

Bendall, H. and Stent, A.F. (2003), "Investment strategies in market uncertainty", Maritime Policy and Management, Vol. 30 No. 4, pp. 293-303.

Bendall, H.B. and Stent, A.F. (2007), "Maritime investment strategies with a portfolio of real options", Maritime Policy and Management, Vol. 34 No. 5, pp. 441-452.

Bogdan, R.C. and Biklen, S.K. (1992), Qualitative Research for Education: An Introduction to Theory and Methods, Allyn and Bacon, Boston.

Bulut, E., Duru, O. and Yoshida, S. (2012), “A fuzzy integrated logical forecasting (FILF) model of time charter rates in dry bulk shipping: a vector autoregressive design of fuzzy time series with fuzzy c-means clustering", Maritime Economics and Logistics, Vol. 14 No. 3, pp. 300-312. 
Bulut, E., Duru, O. and Yoshida, S. (2013), "Market entry, asset returns, and irrational exuberance: asset management anomalies in dry cargo shipping", International Journal of Shipping and Transport Logistics, Vol. 5 No. 6, pp. 653-667.

Cariou, P. and Wolff, F.C. (2011), "Ship-owners' decisions to outsource vessel management”, Transport Reviews, Vol. 31 No. 6, pp. 709-724.

Carter, C., Kaufmann, L. and Michel, A. (2007), "Behavioral supply management: a taxonomy of judgment and decision- making biases", International Journal of Physical Distribution and Logistics Management, Vol. 37 No. 8, pp. 631-669.

Celik Girgin, S., Karlis, T. and Nguyen, H.O. (2018), "A critical review of the literature on firm-level theories on ship investment", International Journal of Financial Studies, Vol. 6 No. 1, pp. 1-19.

Cetin, IB. and Cerit, A.G. (2014), "Turkish shipowners' perceptions of third party ship management companies: a market research study", Dokuz Eylül University Maritime Faculty Journal, Vol. 6 No. 1, pp. 111-136.

Chiste, C. and van Vuuren, G. (2014), "Investigating the cyclical behavior of the dry bulk shipping market”, Maritime Policy and Management, Vol. 41 No. 1, pp. 1-19.

Christie, W.G. and Huang, R.D. (1995), "Following the pied piper: do individual returns herd around the market?”, Financial Analysts Journal, Vol. 51 No. 4, pp. 31-37.

Cohen, B.L. and Wallsten, T.S. (1992), "The effect of constant outcome value on judgments and decision making given linguistic probabilities", Journal of Behavioral Decision Making, Vol. 5 No. 1, pp. 53-72.

Daniel, K., Hirshleifer, D. and Subrahmanyam, A. (1998), "Investor psychology and security market under- and overreactions", The Journal of Finance, Vol. 53 No. 6, pp. 1839-1885.

Dikos, G. and Marcus, H. (2003), "The term structure of second-hand prices: a structural partial equilibrium model", Maritime Economics and Logistics, Vol. 5 No. 3, pp. 251-267.

Drobetz, W., Haller, R. and Meier, I. (2016), "Cash flow sensitivities during normal and crisis times: evidence from shipping”, Transportation Research Part A: Policy and Practice, Vol. 90, pp. 26-49.

Duru, O. (2013), "Irrational exuberance, overconfidence and short termism: knowledge to action asymmetry in shipping asset management", The Asian Journal of Shipping and Logistics, Vol. 29 No. 1, pp. 43-58.

Duru, O. (2016), "Motivations behind irrationality in the shipping asset management: review of fundamental theories and practical challanges”, Maritime Business Review, Vol. 1 No. 2, pp. 163-184.

Duru, O. and Yoshida, S. (2009), "Judgmental forecasting in the dry bulk shipping business: statistical vs judgmental approach", The Asian Journal of Shipping and Logistics, Vol. 25 No. 2, pp. 189-217.

Fan, L. and Luo, M. (2013), "Analyzing ship investment behaviour in liner shipping”, Maritime Policy and Management, Vol. 40 No. 6, pp. 511-533.

Fan, L. and Yin, J. (2016), “Analysis of structural changes in container shipping”, Maritime Economics and Logistics, Vol. 18 No. 2, pp. 174-191.

Fan, S., Ji, T., Gordon, W. and Rickard, B. (2013), "Forecasting Baltic dirty tanker index by applying wavelet neural networks", Journal of Transportation Technologies, Vol. 3 No. 1, pp. 68-87.

Gervais, S. and Odean, T. (2001), "Learning to be overconfident", Review of Financial Studies, Vol. 14 No. 1, pp. 1-27.

Gioia, D.A., Corley, K.G. and Hamilton, A.L. (2013), "Seeking qualitative rigor in inductive research: notes on the gioia methodology", Organizational Research Methods, Vol. 16 No. 1, pp. 15-31.

Glen, D. (1997), "The market for second-hand ships: further results on efficiency using cointegration analysis", Maritime Policy and Management, Vol. 24 No. 3, pp. 245-260. 


\section{MABR}

6,4

Goldberg, J. and von Nitzsch, R. (2001), Behavioral Finance, John Wiley and Sons Ltd., West Sussex.

Gong, S.X., Ye, H.Q. and Zeng, Y.Y. (2013), "Impacts of the recent financial crisis on ship impacts of the recent financial crisis on ship", Maritime Policy and Management, Vol. 40 No. 1, pp. 1-9.

Graham, J.R., Harvey, C.R. and Huang, H. (2009), "Investor competence, trading frequency and home bias", Management Science, Vol. 55 No. 7, pp. 1094-1106.

Greenwood, R. and Hanson, S. (2015), "Waves in ship prices and investment”, The Quarterly Journal of Economics, Vol. 130 No. 1, pp. 55-109.

Hale, C. and Vanags, A. (1992), "The market for second-hand ships: some results on efficiency using cointegration", Maritime Policy and Management, Vol. 19 No. 1, pp. 31-39.

Hampton, M. (1991), Long and Short Shipping Cycles: The Rhythms and Psychology of Shipping Markets, A Cambridge Academy of Transport Monograph, Cambridge.

Hirshleifer, D. (2001), "Investor psychology and asset pricing”, The Journal of Finance, Vol. 56 No. 4, pp. 1533-1597.

Hogarth, R.M. (1987), Judgment and Choice, Wiley, New York, NY.

Kahneman, D. and Riepe, M. (1998), "Aspects of investor psychology", The Journal of Portfolio Management, Vol. 24 No. 4, pp. 52-65.

Kahneman, D. and Tversky, A. (1979), "Prospect theory: an analysis of decision under risk", Econometrica, Vol. 47 No. 2, pp. 263-292.

Kahneman, D., Knetsch, J.L. and Thaler, R.T. (1991), "Anomalies: the endowment effect, loss aversion and status quo bias", Journal of Economic Perspectives, Vol. 5 No. 1, pp. 193-206.

Kalouptsidi, M. (2014), "Time to build and fluctuations in bulk shipping", American Economic Review, Vol. 104 No. 2, pp. 564-608.

Kang, J.K. and Stulz, R.M. (1997), "Why is there a home bias? An analysis of foreign portfolio equity ownership in Japan”, Journal of Financial Economics, Vol. 46 No. 1, pp. 3-28.

Kavussanos, M. and Alizadeh, A. (2002), "Efficient pricing of ships in the dry bulk sector of the shipping industry", Maritime Policy and Management, Vol. 29 No. 3, pp. 303-330.

Kvale, S. (1996), Interviews: An Introduction to Qualitative Research Interviewing, Sage, Thousand Oaks.

Lyungqvist, A. and Wilhelm, W.J. (2003), "IPO pricing in the dot-com bubble", The Journal of Finance, Vol. 58 No. 2, pp. $723-752$.

McGregor, D. (1938), "The major determinants of the prediction of social events", The Journal of Abnormal and Social Psychology, Vol. 33 No. 2, pp. 179-204.

Marlow, P. (1991), "Shipping and investment incentives: a trilogy part 3: the effectiveness of investment incentives for shipping - the UK experience 1950-1987", Maritime Policy and Management, Vol. 18 No. 4, pp. 283-311.

Merikas, A.G., Merika, A.A. and Koutroubousis, G. (2008), "Modelling the investment decision of the entrepreneur in the tanker sector: choosing between a second-hand vessel and a newly built one", Maritime Policy and Management, Vol. 35 No. 5, pp. 433-447.

Miles, M.B. and Huberman, A.M. (1994), Qualitative Data Analysis: An Expanded Sourcebook, Sage Publications, Thousand Oaks.

Munm, Z.H. and Schramm, H.J. (2020), "Forecasting container freight rates for major trade routes: a comparison of artificial neural networks and conventional models", Maritime Economics and Logistics, doi: 10.1057/s41278-020-00156-5.

Nofsinger, J.R. and Sias, R.W. (1999), "Herding and feedback trading by institutional and individual investors", The Journal of Finance, Vol. 54 No. 6, pp. 2263-2295.

Olsen, R.A. (1997), "Desirability bias among professional investment managers: some evidence from experts", Journal of Behavioral Decision Making, Vol. 10 No. 1, pp. 65-72. 
Panayides, P.M., Lambertides, N. and Savva, C.S. (2011), "The relative efficiency of shipping companies", Transportation Research Part E: Logistics and Transportation Review, Vol. 47 No. 5, pp. 681-694.

Patton, M. (2002), Qualitative Research and Evaluation Methods, Sage, Thousand Oaks, Vol. 3.

Behavioral biases in ship investments

Rabin, M. (1998), "Psychology and economics”, Journal of Economic Literature, Vol. 36 No. 1, pp. 11-46.

Samuelson, W. and Zeckhauser, R. (1988), "Status quo bias in decision making”, Journal of Risk and Uncertainty, Vol. 1 No. 1, pp. 7-59.

Scarsi, R. (2007), “The bulk shipping business: market cycles and shipowners, biases”, Maritime Policy and Management, Vol. 34 No. 6, pp. 577-590.

Shefrin, H. (2000), Beyond Greed and Fear: Understanding Behavioral Finance and the Psychology of Investing, Harvard Business School Press, Boston.

Statman, M., Thorley, S. and Vorkink, V. (2006), "Investor overconfidence and trading volume", Review of Financial Studies, Vol. 19 No. 4, pp. 1531-1565.

Stokes, P. (1996), "Problems faced by the shipping industry in raising capital in the securities markets", Maritime Policy and Management, Vol. 23 No. 4, pp. 397-405.

Stone, D. and Ziemba, W.T. (1993), "Land and stock prices in Japan”, Journal of Economic Perspectives, Vol. 7 No. 3, pp. 149-165.

Thaler, R.H. (1980), “Toward a positive theory of consumer choice”, Journal of Economic Behavior and Organization, Vol. 1 No. 1, pp. 39-60.

Tsolakis, S., Cridland, C. and Haralambides, H.E. (2003), "Econometric modelling of second-hand ship prices", Maritime Economics and Logistics, Vol. 5 No. 4, pp. 347-377.

Tversky, A. and Kahneman, D. (1974), "Judgment under uncertainty: heuristics and biases”, Science, Vol. 185 No. 4157, pp. 1124-1131.

Wolcott, H. (1994), Transforming Qualitative Data: Description, Analysis and Interpretation, Sage Publications, Thousand Oaks.

Wright, W.F. and Anderson, U. (1989), "Effects of situation familiarity and financial incentives on use of the anchoring and adjustment heuristic for probability assessment", Organizational Behavior and Human Decision Processes, Vol. 44 No. 1, pp. 68-82.

Yin, R.K. (1994), "Discovering the future of the case study method in evaluation research", Evaluation Practive, Vol. 15 No. 3, pp. 283-290.

Yin, J., Wu, Y. and Lu, L. (2018), "Assessment of investment decision in the dry bulk shipping market based on real options thinking and the shipping cycle perspective", Maritime Policy and Management, Vol. 46 No. 3, pp. 330-343.

\section{Corresponding author}

Ersin Firat Akgul can be contacted at: eakgul@bandirma.edu.tr 
MABR

6,4

\section{Appendix 1}

\section{Semi-structured interview questions}

- What are your thoughts regarding the factors that affect ship investments?

- What are your thoughts regarding techniques used for the evaluation of ship investment alternatives?

- What are your thoughts regarding financing sources of ship investments in Turkey?

- What are your thoughts regarding the data sources that ship investors in Turkey use to monitor the market?

- What are your thoughts regarding the effect of the market conditions on ship investments?

- What are your thoughts regarding the ability of ship investors in Turkey to read the market correctly and timing in ship investments?

- What are your thoughts regarding ship investment behavior of ship investors in Turkey when you take into account the market conditions that emerged before and after the global financial crisis in 2008 ?

- What are your thoughts regarding the effect of profile of ship investors on ship investments in Turkey?

- What are your thoughts regarding the effect of the business models adopted by shipping companies in Turkey on ship investments?

- What are your thoughts regarding the effect of instincts and experiences of ship investors on ship investments in Turkey?

- What are your thoughts regarding the effect of the behavior of other market participants on ship investments in Turkey?

- What are your thoughts regarding the effect of the behavior of ship investors in maritime nations on ship investments in Turkey?

- What are your thoughts regarding the effect of intermediaries such as banks, brokers, etc. On ship investments in Turkey?

- What are your thoughts regarding the effect of charterers on ship investments in Turkey?

- What are your thoughts regarding the effect of ship specifications on the ship investments in Turkey?

- What are your thoughts regarding the effects of external developments such as political, economic, technological, etc. abroad on ship investments in Turkey?

- What are your thoughts regarding incentives on ship investments in Turkey? 

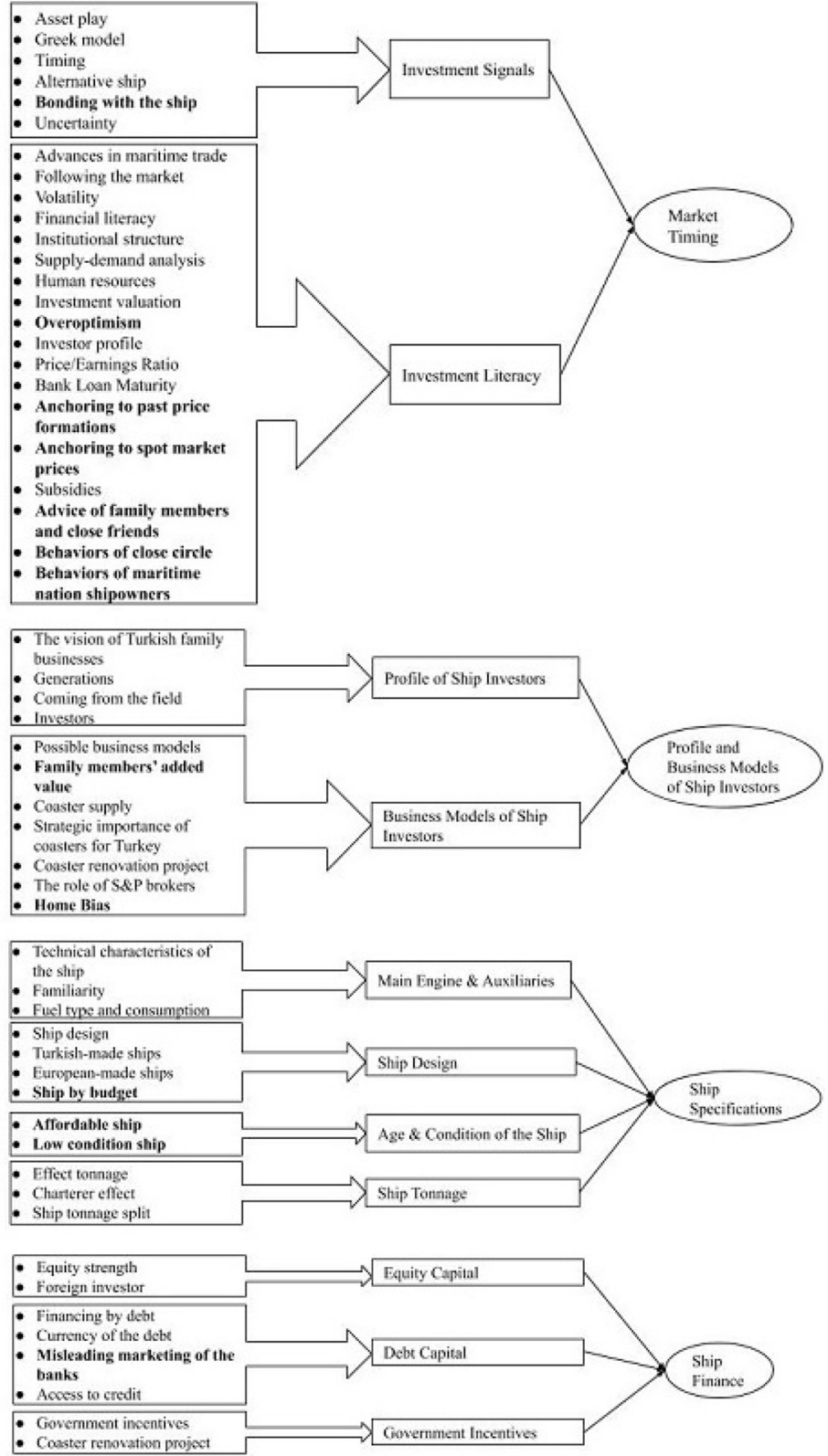

Figure A1. Data structure 